\title{
Pawel Krzemiński
}

Zakład Zagospodarowania Przestrzennego

Instytut Geografii i Rozwoju Regionalnego

Uniwersytet Wrocławski

\section{Specjalne strefy ekonomiczne jako stymulator przedsiębiorczości}

Przejście od gospodarki centralnie planowanej do gospodarki wolnorynkowej objawiło się w Polsce i innych krajach Europy Środkowo-Wschodniej ogromną zapaścią gospodarczą. Produkcja przemysłowa w latach 1990-1992 spadła o 30\%. Wiele zakładów upadło, inne zaczęły się borykać problemami, przed jakimi stawiała je gospodarka wolnorynkowa. Koniecznością stało się opracowanie mechanizmów przyspieszających rozwój gospodarczy kraju, a szczególnie obszarów najbardziej problemowych.

Jednym z głównych zabiegów stymulujących rozwój społeczno-gospodarczy jest pobudzanie przedsiębiorczości ludności poprzez stworzenie odpowiednich warunków funkcjonowania przedsiębiorstw. Nie bez powodu przedsiębiorczość bywa czasami uważana za czwarty czynnik produkcji, obok pracy, ziemi i kapitału. Pośród licznych rozwiązań stosowanych w celu ułatwienia prowadzenia działalności gospodarczej znalazło się również powoływanie specjalnych stref ekonomicznych (SSE) na obszarach najsłabiej rozwiniętych lub dotkniętych problemem ponadprzeciętnego bezrobocia. Ich zadaniem jest nie tylko przyciąganie inwestycji z zewnątrz, ale również pobudzenie przedsiębiorczości społeczności lokalnej.

Specjalna strefa ekonomiczna to wydzielona i niezamieszkana część terytorium kraju, w której działalność gospodarcza może być prowadzona na preferencyjnych warunkach. Preferencje te to ulgi w podatkach dochodowym i od nieruchomości, częściowy zwrot nakładów inwestycyjnych i zwrot kosztów pracy. Tak znaczne korzyści dla inwestorów przyczyniły się do dużej popularności tego narzędzia polityki regionalnej. Obecnie w Polsce działa 14 specjalnych stref ekonomicznych, obejmujących ponad 220 podstref zlokalizowanych we wszystkich województwach.

Główne cele powstania SSE, zapisane w ustawie o specjalnych strefach ekonomicznych, to tworzenie nowych miejsc pracy na obszarach o wysokim bezrobociu strukturalnym i przyspieszenie rozwoju gospodarczego części terytorium kraju poprzez rozwój określonych dziedzin działalności gospodarczej, dywersyfikację struktury produkcji i przełamanie monokultury przemysłu oraz rozwój eksportu. Innymi celami są: zwiększenie konkurencyjności wytwarzanych wyrobów i świadczonych usług, wspomaganie lokalnej infrastruktury technicznej oraz pobudzanie lokalnej przedsiębiorczości.

Niniejsze opracowanie ma na celu przedstawienie wpływu specjalnych stref ekonomicznych na rozwój przedsiębiorczości. Wyjściem do rozważań było przypuszczenie, że tereny objęte zasięgiem strefy charakteryzują się lepszymi wskaźnikami ekonomicznymi niż obszary sąsiadujące, ale nie leżące w obrębie strefy. Dokonano zatem porównania sytuacji obszarów objętych zasięgiem SSE i leżących poza ich oddziaływaniem. Z uwagi na dostępność danych większości obliczeń dokonano w odniesieniu do poziomu NTS 4. Wyniki badania pozwalają 
odpowiedzieć na pytanie: W jaki sposób wszelkiego rodzaju ulgi i preferencje stosowane w ramach stref wpływają na wzrost przedsiębiorczości?

\section{Dotychczasowe efekty funkcjonowania specjalnych stref ekonomicznych}

Pierwszą polską specjalną strefą ekonomiczną jest powstała w 1995 r. SSE EURO-PARK Mielec. Jest to jednocześnie strefa, która odniosła największy sukces. Obecnie w Polsce funkcjonuje 14 SSE, z których większość powstała w 1997 r. Do tej pory (30.06.2008 r.) strefy przyciągnęły ponad 1,1 tys. przedsiębiorców, którzy otrzymali zezwolenia na prowadzenie działalności. Od początku funkcjonowania stref zainwestowano w nich ponad 51,2 mld zł. Pozwoliło to na utworzenie 151,8 tys. nowych miejsc pracy oraz utrzymanie 46,1 tys. dotychczasowych, które bez tych inwestycji musiałyby zostać zlikwidowane. Należy pamiętać, że na mocy ustawy z 30 maja 2008 r. wszystkie strefy mogą zajmować maksymalnie 20 tys. ha, co stanowi jedynie $0,06 \%$ powierzchni kraju, przy odsetku pracujących w SSE w ogóle pracujących wynoszącym $1,27 \%$.

Ryc. 1. Rozmieszczenie SSE w Polsce (stan 30.06.2008 r.)

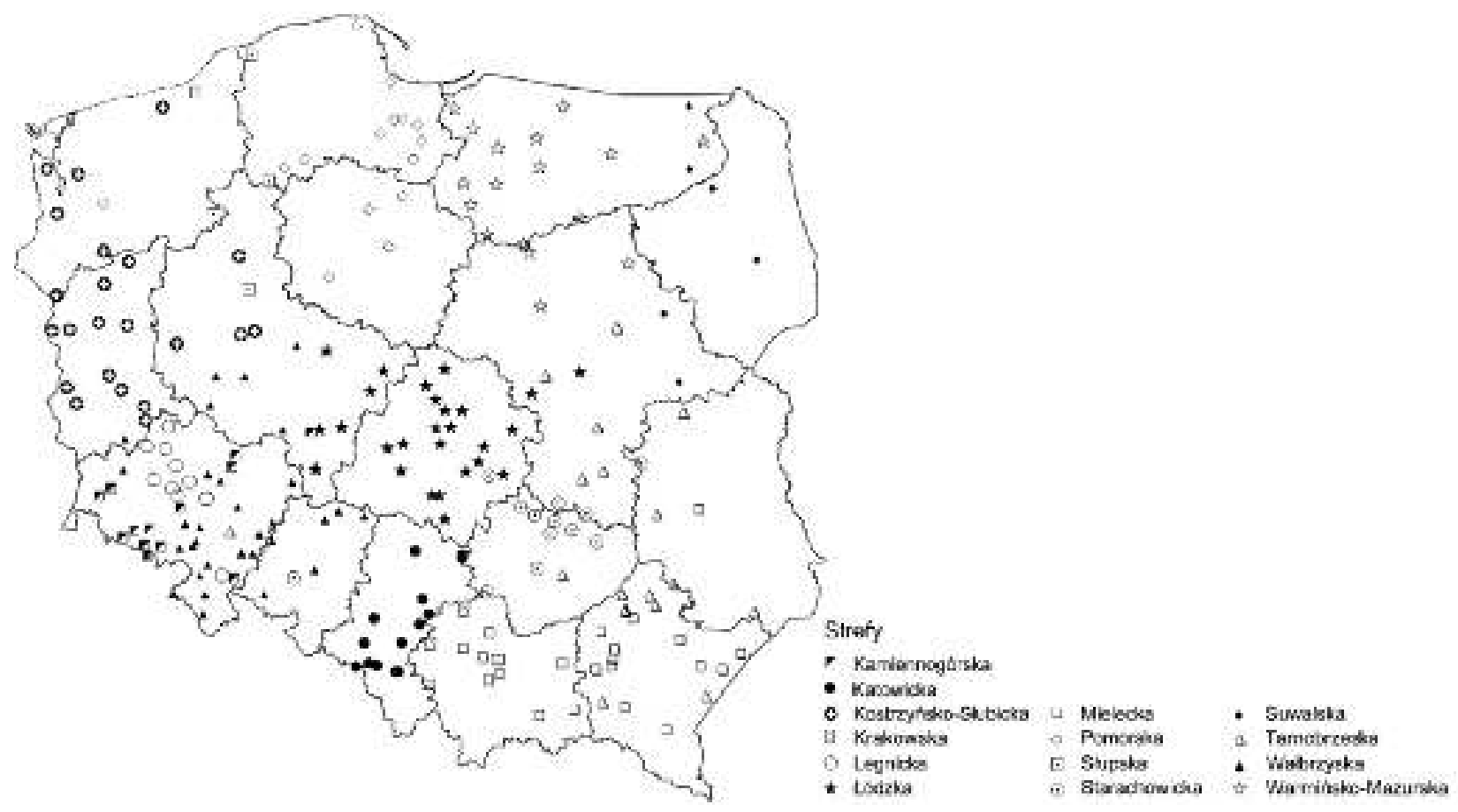

Źródło: opracowanie autora.

Działalność gospodarcza prowadzona jest w ponad 220 podstrefach zlokalizowanych we wszystkich województwach (ryc. 1). Warto zwrócić uwagę, że ich rozmieszczenie jest nierównomierne i niekoniecznie zgodne z pierwotnymi założeniami projektu, czyli pobudzaniem i wspieraniem obszarów w najtrudniejszej sytuacji gospodarczej. Najwięcej podstref powstało w województwach zachodniej Polski, których sytuacja ekonomiczna nie była wcale najgorsza. Najsłabsze ekonomicznie województwa, podlaskie i lubelskie, obszarów uprzywilejowanych mają niewiele. Poddaje to w wątpliwość kryteria włączania terenów do strefy.

Pomijając kwestie związane z poszerzaniem granic SSE o nowe obszary oraz skutecznością tego instrumentu polityki regionalnej, trzeba przyznać, że dynamika ich rozwoju jest imponująca (tab. 1). W latach 2001-2007 przeciętny roczny wzrost nakładów inwestycyjnych wynosił około $30 \%$, a liczba miejsc pracy corocznie zwiększała się o ponad 20\%, osiągając w 2005 r. nawet $45 \%$. 
Tab. 1. Efekty funkcjonowania SSE w latach 2001-2008

\begin{tabular}{|c|c|c|c|c|c|c|}
\hline Stan w dniu & \multicolumn{2}{|c|}{ Liczba ważnych pozwoleń } & \multicolumn{2}{|c|}{$\begin{array}{c}\text { Naklady inwestycyjne } \\
\text { (w mln zl) }\end{array}$} & \multicolumn{2}{|c|}{$\begin{array}{c}\text { Liczba miejsc pracy } \\
\text { (w tys.) }\end{array}$} \\
\hline 31.12 .2001 r. & 703 & $\begin{array}{c}\text { zmiana w stos. do } \\
\text { roku poprzedniego }\end{array}$ & 9287 & $\begin{array}{l}\text { zmiana w stos. do } \\
\text { roku poprzedniego }\end{array}$ & 42,3 & $\begin{array}{c}\text { zmiana w stos. do } \\
\text { roku poprzedniego }\end{array}$ \\
\hline 31.12 .2002 r. & 690 & $-1,8 \%$ & 13086 & $+40,9 \%$ & 50,8 & $+20,1 \%$ \\
\hline 31.12 .2003 r. & 670 & $-2,9 \%$ & 15269 & $+16,7 \%$ & 62,1 & $+22,2 \%$ \\
\hline 31.12 .2004 r. & 679 & $+1,4 \%$ & 19927 & $+30,5 \%$ & 77,6 & $+25,0 \%$ \\
\hline 31.12 .2005 r. & 767 & $+13,0 \%$ & 25707 & $+29,0 \%$ & 112,2 & $+44,6 \%$ \\
\hline 31.12 .2006 r. & 924 & $+20,5 \%$ & 35430 & $+37,8 \%$ & 146,4 & $+30,5 \%$ \\
\hline 31.12 .2007 r. & 1059 & $+14,6 \%$ & 46085 & $+30,1 \%$ & 182,4 & $+24,6 \%$ \\
\hline 30.06 .2008 r. & 1131 & $+6,9 \%$ & 51206 & $+11,1 \%$ & 198,0 & $+8,6 \%$ \\
\hline
\end{tabular}

Źródło: opracowanie autora na podstawie: Efekty funkcjonowania specjalnych stref ekonomicznych, Ministerstwo Gospodarki, 2001-2008.

O ile liczba utworzonych miejsc pracy może świadczyć co najwyżej o wpływie na stopę bezrobocia $\mathrm{w}$ otoczeniu lokalnym danej strefy, o tyle wartość nakładów inwestycyjnych na jedno utworzone miejsce pracy ukazuje poziom kapitałochłonności inwestycji (ryc. 2). W strefach: legnickiej, katowickiej i wałbrzyskiej nakłady te znacznie przewyższają średnią. Szczególnie wyróżnia się Legnicka SSE, w której wskaźnik kapitałochłonności wynosi prawie 450 tys. zł. Świadczy to o nowoczesności zastosowanych rozwiązań technologicznych oraz wysokim stopniu automatyzacji produkcji, do której obsługi wymagana jest wysoko wykwalifikowana kadra. W tych trzech strefach istotną rolę odgrywają przedsiębiorcy z branży motoryzacyjnej, co tłumaczy wielkość nakładów.

Innym miernikiem określającym profil inwestorów w strefie jest wielkość nakładów poniesionych na jedno wydane zezwolenie. Wskaźnik ten przedstawia się podobnie jak wcześniejszy - występują jedynie niewielkie różnice w kolejności poszczególnych SSE. Jest on jednym z czynników służących do badania zakorzenienia przedsiębiorstw (głównie zagranicznych) w Polsce. Im większe nakłady poniósł inwestor na rozpoczęcie działalności, tym dłużej powinien w danym miejscu funkcjonować. Można się spodziewać, że inwestycje warte kilkadziesiąt czy kilkaset milionów złotych nie znikną wraz z wygaśnięciem ulg i końcem funkcjonowania strefy, ale pozostaną w krajobrazie gospodarczym na dłużej.

Przedsiębiorstwa lokujące swoją działalność w strefach to zazwyczaj średnie i duże zakłady produkcyjne. Przeciętne nakłady nawet w najsłabiej pod tym względem wypadającej Starachowickiej SSE wyniosły ponad $10 \mathrm{mln} \mathrm{zł}$. W pewnym stopniu było to uwarunkowane ustawą, która umożliwiała lokowanie działalności w obrębie stref jedynie przedsiębiorcom inwestującym określoną kwotę lub tworzącym określoną liczbę miejsc pracy, przy czym preferowana była działalność przemysłowa. W 2005 r. warunki zostały nieco zliberalizowane. Od tej pory o lokalizację w strefach mogą starać się także przedsiębiorstwa reprezentujące sektor usług nowoczesnych, zwany Business Process Offshoring (BPO). Są to głównie usługi z zakresu finansów, księgowości, administracji, zarządzania zasobami ludzkimi oraz obsługi klientów zewnętrznych (call centers). Według szacunków, objęcie strefami przedsiębiorstw z branży BPO może wygenerować na ich terenie kilkanaście tysięcy nowych miejsc pracy (Korycińska 2005). 
Ryc. 2. Nakłady inwestycyjne poniesione w SSE na jedno miejsce pracy w tys. zł (stan 30.06.2008 r.)

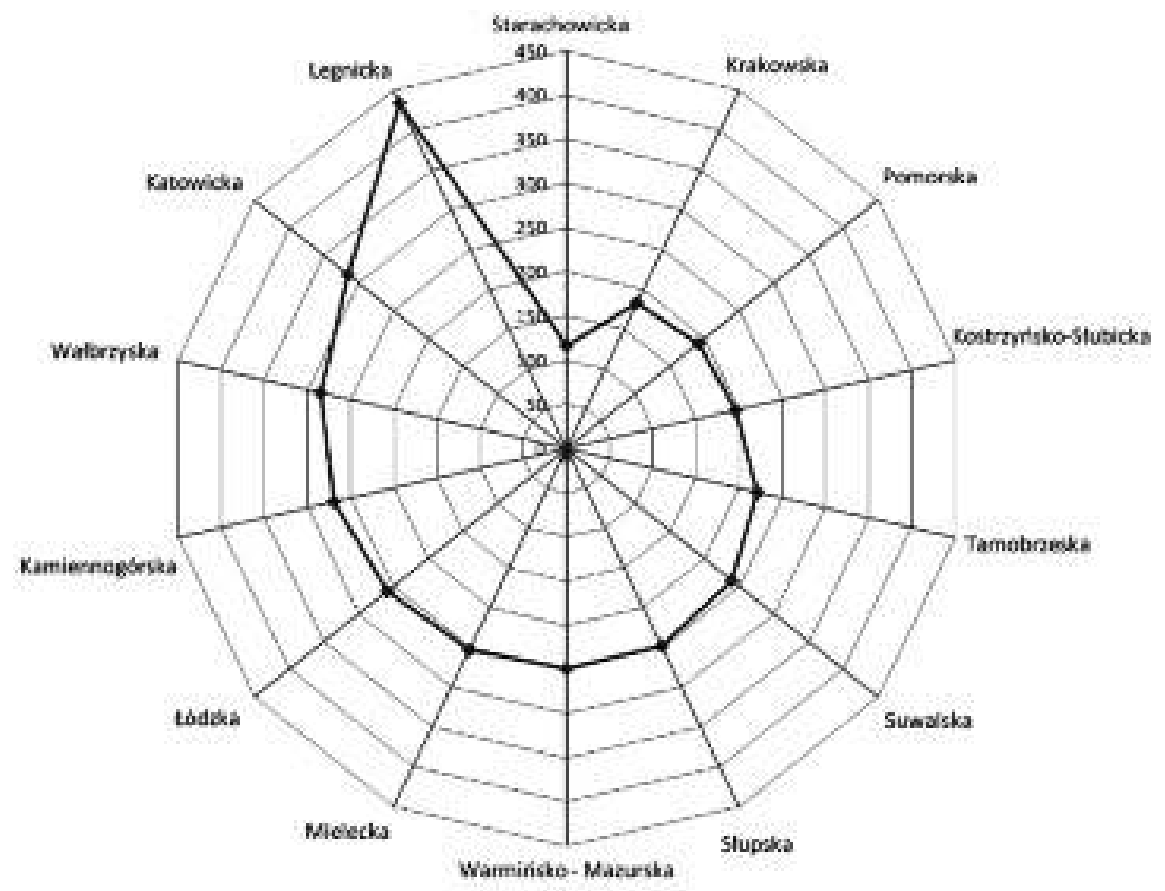

Źródło: opracowanie autora na podstawie: Efekty funkcjonowania specjalnych stref ekonomicznych, Ministerstwo Gospodarki, 2008 r.

Ryc. 3. Nakłady inwestycyjne poniesione w SSE na jedno zezwolenie w tys. zł (stan 30.06.2008 r.)

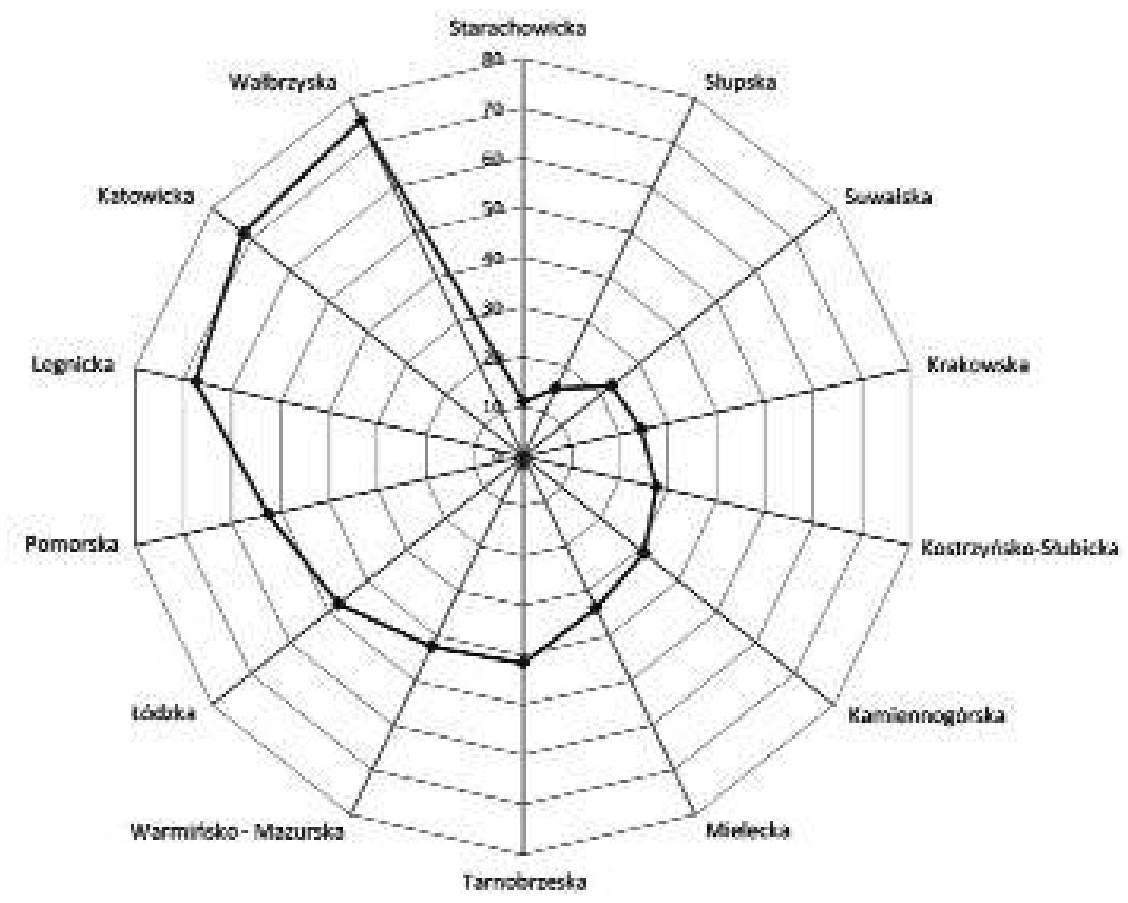

Źródło: opracowanie autora na podstawie: Efekty funkcjonowania specjalnych stref ekonomicznych, Ministerstwo Gospodarki, 2008 r.

Średnia wielkość zatrudnienia w przedsiębiorstwie funkcjonującym w strefie przekracza 180 osób. Oddziaływanie tak dużych zakładów na lokalną gospodarkę nie jest zatem obojętne. Wokół dużych przedsiębiorców powstają sieci kooperantów z różnych branż - od firm projektowych i budowlanych, poprzez przedsiębiorstwa transportowe i telekomunikacyjne, instytucje otoczenia biznesu, po dostawców komponentów potrzebnych do produkcji. $\mathrm{Z}$ badań przepro- 
wadzonych w strefie EURO-PARK Mielec (Domański, Gwosdz 2005) wynika, że na 1000 miejsc pracy utworzonych przez przedsiębiorstwa działające $\mathrm{w}$ obrębie stref powstaje co najmniej 350 miejsc pracy w otoczeniu lokalnym poza strefą. Jeszcze bardziej optymistyczne dane wynikają z raportu KPMG (2007): każde 100 miejsc pracy utworzonych w SSE generuje, w zależności od branży, 50-100 miejsc pracy w jej bezpośrednim otoczeniu.

\section{Wpływ specjalnych stref ekonomicznych na rozwój przedsiębiorczości}

Omawiając efekty funkcjonowania stref, nie można pominąć ich wpływu na otoczenie. Wpływ SSE na obszar, na którym jest ona zlokalizowana, nie ogranicza się tylko do efektów bezpośrednich w postaci stworzenia miejsc pracy przez inwestora. Jest to trudne do wyrażenia w wartościach liczbowych, ale można stwierdzić, że zaspokojenie potrzeb związanych z budową i funkcjonowaniem nowego zakładu przemysłowego stymuluje rozwój wszystkich dziedzin życia gospodarczego regionu. Nowe inwestycje kreują dodatkowy popyt na różne towary i usługi, które z powodzeniem starają się zaspokoić małe firmy, funkcjonujące w charakterze poddostawców dla firm większych. Wzrasta zatrudnienie w firmach budowlanych, rozwijają się przedsiębiorstwa transportowe, wzrasta popyt na usługi finansowe i powstają nowe miejsca pracy w firmach kooperujących. Są to tzw. zaopatrzeniowe efekty mnożnikowe. Innymi korzyściami pobudzającymi lokalne gospodarki są tzw. dochodowe efekty mnożnikowe. Objawiają się one zwiększeniem popytu na dobra konsumpcyjne wywołane wzrostem siły nabywczej ludności. Powstają niewielkie rodzinne przedsiębiorstwa handlowe, rozwija się cała gama usług bytowych, wzrasta popyt na usługi edukacyjne oraz kulturalne.

Wpływ na poszczególne dziedziny gospodarki zauważalny jest już od momentu podjęcia decyzji o utworzeniu obszaru preferencyjnego gospodarowania. W pierwszej kolejności wzrasta popyt na usługi geodezyjne i projektowe, związane z przygotowaniem inwestycji. Kadra menadżerska, pochodząca często spoza regionu lub - w przypadku przedsiębiorstw z obcym kapitałem - z zagranicy, przyczynia się do rozwoju bazy hotelowej i gastronomicznej, a z czasem także do ożywienia lokalnego rynku nieruchomości. Rozwijają się usługi telekomunikacyjne: telefonii stacjonarnej i komórkowej oraz internetu. Eksporterzy, którzy mają spory udział w przedsiębiorstwach zlokalizowanych w SSE, wymuszają powstawanie nowych agencji celnych oraz rozwój usług transportowych. To właśnie lokalne firmy transportowe są jednym z największych beneficjentów SSE. Wzmożone zapotrzebowanie zauważalne jest nie tylko w przypadku towarowych przewozów kolejowych, często w wykorzystaniem nieczynnych już bocznic, ale przede wszystkim w przypadku niewielkich, często jednoosobowych firm transportowych. W celu zbadania wpływu strefy na ten sektor opracowano specjalny miernik, zwany wskaźnikiem przedsiębiorczości w zakresie usług transportowych. Liczony jest on jako liczba przedsiębiorstw sekcji I w przeliczeniu na 1000 mieszkańców. Niezwykle ważną rolę pełnią także instytucje otoczenia biznesu, a więc firmy świadczące usługi z zakresu bankowości, ubezpieczeń i leasingu. Bardzo często instytucje te zakładają filie w pobliżu stref, aby ułatwić przedsiębiorcom prowadzenie działalności. W dobie wszechobecnej informacji nie można zapomnieć o istotnej roli usług informatycznych. Powstawanie nowych firm wiąże się ze wzrostem zapotrzebowania na wszelkiego rodzaju usługi informatyczne, poczynając od firm dostarczających sprzęt komputerowy i inne niezbędne narzędzia biurowe, a kończąc na przedsiębiorstwach produkujących oprogramowanie. Badania przeprowadzone w strefie mieleckiej (Domański, Gwosdz 2005) wykazały, że w ciągu kilku lat liczba oferentów na rynku sprzętu komputerowego i oprogramowania, sprzętu kserograficznego, faksów, centrali telefonicznych i kas fiskalnych wzrosła pięciokrotnie. Oczywiście, część tego wzrostu przypada na ogólny rozwój rynku, ale rola popytu ze strony firm działających w SSE jest w nim 
z pewnością istotna. W końcu popyt ze strony nowych przedsiębiorstw przekłada się na wzrost zapotrzebowania na usługi słabo dotychczas wykorzystywane. Można do nich zaliczyć usługi pocztowe, catering, pralnie odzieży roboczej, usługi ochrony mienia, sprzątanie i utrzymanie czystości w obiektach, usługi komunalne itp.

Ożywienie widoczne jest także na rynku budowlanym. Powstawanie nowych obiektów, począwszy od uzbrojenia i przygotowania terenu pod inwestycje po budowę zakładów od podstaw, jest szansą dla lokalnych przedsiębiorstw budowlanych - wykonawców i podwykonawców - na rozwój i uczestniczenie w dużych przedsięwzięciach. Objawia się to przede wszystkim wzrostem zatrudnienia, także sezonowego, związanego z wykonywaniem robót budowlanych. Innym widocznym efektem jest wzrost wielkości sprzedaży materiałów budowlanych.

Zmiany następują także w szeroko pojętej edukacji. Szkoły zawodowe dostosowują profil do zapotrzebowania inwestorów. Rośnie liczba uczestniczących we wszelkiego rodzaju kursach podnoszących umiejętności i kwalifikacje, od kursów komputerowych poczynając, przez naukę języków obcych, szkolenia z zakresu marketingu i księgowości, na specjalistycznych kursach zawodowych kończąc. Chcąc sprostać popytowi na wyżej wykwalifikowane kadry, swoje filie w pobliżu SSE tworzą także uczelnie wyższe.

Do pozostałych długofalowych korzyści dla społeczności lokalnej należą także:

- przełamanie tradycji monokultury przemysłowej na rzecz dywersyfikacji branżowej;

- wprowadzenie nowych technologii oraz know-how;

- wzrost kwalifikacji pracowników lokalnych firm;

- powstanie więzi kooperacyjnych między producentami działającymi w SSE a firmami ulokowanymi w jej sąsiedztwie;

- poprawa jakości towarów i usług;

- udoskonalenie form zarządzania i organizacji pracy;

- umożliwienie lokalnym przedsiębiorcom dostępu do kapitału i nowych rynków zbytu;

- rozbudowa infrastruktury technicznej, służącej nie tylko inwestorom w strefach, ale również społeczności lokalnej, wywołanie potrzeby rozbudowy i modernizacji infrastruktury drogowej w mieście;

- rozbudowa infrastruktury społecznej, czyli placówek służby zdrowia, szkół, centrów kulturalnych i sportowych.

Nie należy zapominać o wpływie stref na budżet miasta i gmin ościennych. Pomimo braku wpływów z podatków od nieruchomości i częściowo obniżonego podatku od osób prawnych, wpływy z podatków pośrednich związanych ze wzrostem zatrudnienia, siły nabywczej ludności oraz podatków płaconych przez kooperantów spoza stref $\mathrm{z}$ nawiązką rekompensują utracone korzyści finansowe.

Funkcjonowanie SSE przynosi także efekty negatywne. W każdym przypadku ich powstaniu towarzyszyły obawy o ich wpływ na lokalny rynek pracy. Gwosdz i Kwiecińska (2005) wymieniają trzy typy zagrożeń:

- małe i średnie przedsiębiorstwa mogą nie wytrzymać konkurencji z firmami działającymi na warunkach preferencyjnych;

- powstanie SSE spowoduje drenaż rynku pracy (zatrudnianie fachowców z lokalnych firm, zamiast bezrobotnych i absolwentów);

- strefa przyciągnie rzesze ludzi z zewnątrz, przyczyniając się do powstania silnej konkurencji na rynku pracy.

Badania przeprowadzone w mieleckiej strefie wykazały, że żadne z potencjalnych zagrożeń nie zostało zidentyfikowane. Nie stwierdzono, by przedsiębiorstwa działające w strefach 
przyczyniały się do upadku firm spoza strefy. Zaobserwowano natomiast wzrost płac oraz zwiększenie wymagań pracowników wobec pracodawców. $Z$ badań ankietowych wynika, że 89\% mieszkańców pozytywnie wyraża się o zlokalizowaniu strefy i dostrzega wymierne tego korzyści. Jest to widoczne przede wszystkim na rynku pracy, który stał się znacznie łatwiej dostępny. Bezrobocie, które jeszcze kilka lat temu znacznie przekraczało 20\%, w 2008 r. spadło poniżej $10 \%$. Zasadne wydaje się więc przeprowadzenie podobnej analizy na pozostałych obszarach.

Zbadanie ilościowego wpływu stref na przedsiębiorczość w skali całego kraju jest niezwykle trudne $\mathrm{z}$ powodu braku odpowiednich danych dla poziomu NTS 5, a badanie w skali powiatowej może prowadzić do zbyt dużych uogólnień. Dla uproszczenia jednak przyjęto, że skala lokalna jest tożsama z poziomem NTS 4, czyli powiatami.

Do pomiaru przedsiębiorczości stosuje się najczęściej tzw. wskaźnik przedsiębiorczości - iloraz liczby zarejestrowanych podmiotów gospodarczych i liczby mieszkańców wyrażonej w tysiącach. W przypadku dostępności bardziej szczegółowych danych stosuje się także inne wskaźniki, m.in. liczbę osób z wyższym wykształceniem, przychody ze sprzedaży firm informatycznych, produkcję sprzedaną przemysłu czy modyfikację wskaźnika przedsiębiorczości, uwzględniającą jedynie podmioty sektora MŚP. Przestrzenne zróżnicowanie wskaźnika przedsiębiorczości w powiatach przedstawia ryc. 4.

Ryc. 4. Przestrzenne zróżnicowanie wskaźnika przedsiębiorczości w Polsce w 2007 r.

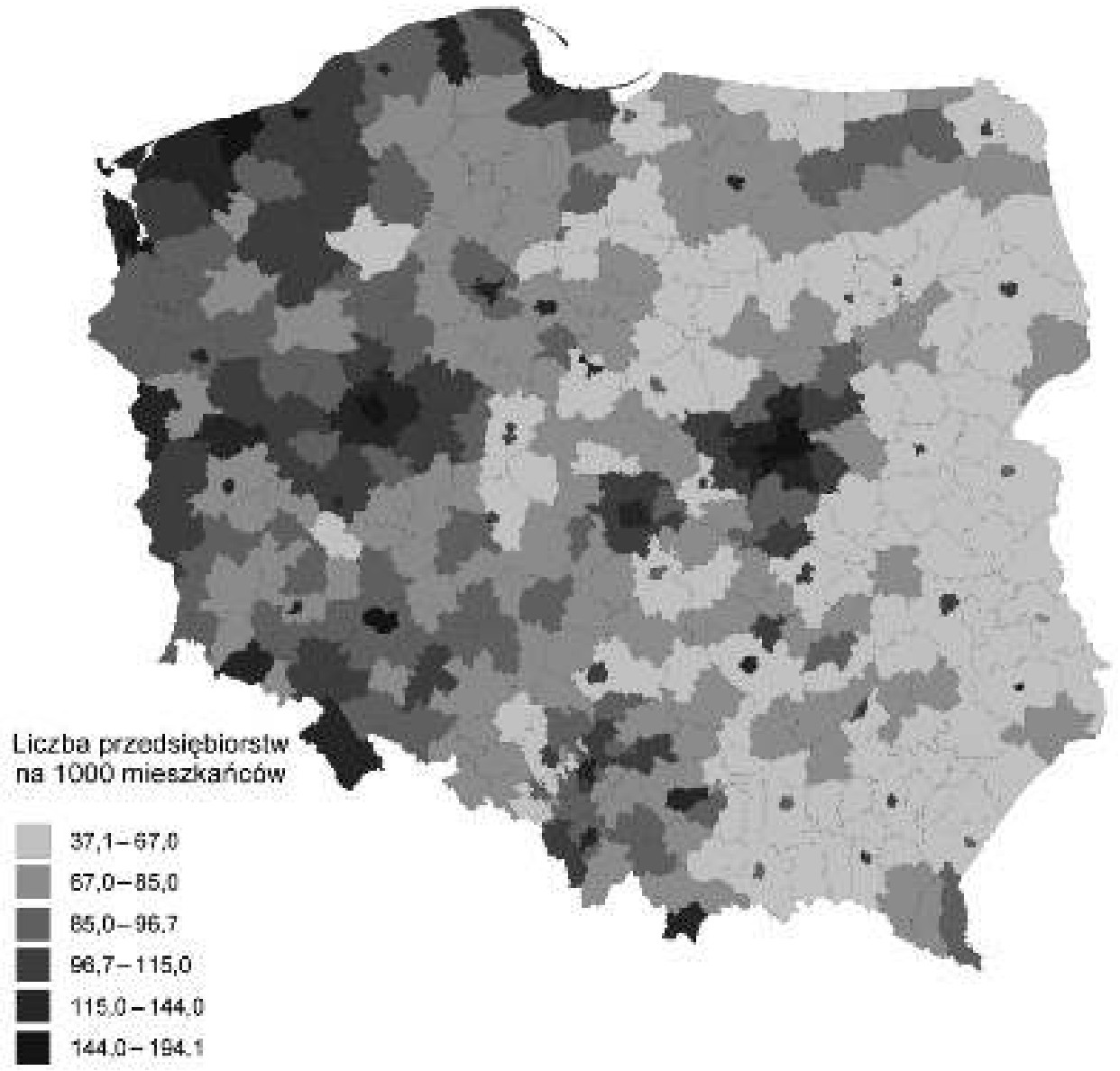

Źródło: opracowanie autora na podstawie danych Banku Danych Regionalnych.

Znacząca dysproporcja regionalna przypomina wiele innych zjawisk społeczno-ekonomicznych. Zdecydowanie na tle kraju wyróżniają się województwa: zachodniopomorskie, wielkopolskie, 
lubuskie, dolnośląskie, mazowieckie i śląskie. W tych województwach zlokalizowana jest większość podstref SSE. Najsłabiej prezentują się regiony wschodnie i południowo-wschodniej Polski. Województwa: podkarpackie, lubelskie i podlaskie mają wskaźniki przedsiębiorczości znacznie na niekorzyść odbiegające od średniej krajowej.

W celu ukazania wpływu stref na rozwój przedsiębiorczości, podzielono powiaty na dwie grupy: 1. w których zlokalizowano podstrefę którejś ze SSE; 2. w których stref nie ma. Następnie porównano wskaźnik przedsiębiorczości w obu grupach (tab. 2). W kolejnym kroku wyeliminowano z analizy powiaty grodzkie, których obecność w badaniu mogłaby zniekształcać obraz. W obu przypadkach wskaźnik przedsiębiorczości był wyższy dla powiatów z grupy 1., przy czym większe różnice widoczne są przy badaniu z wykluczeniem powiatów grodzkich. Warto wspomnieć, że ta różnica systematycznie rośnie w kolejnych latach.

Tab. 2. Wskaźnik przedsiębiorczości w powiatach

\begin{tabular}{|c|c|c|c|c|c|}
\hline \multirow{2}{*}{} & \multirow{2}{*}{ Polska } & \multicolumn{2}{|c|}{$\begin{array}{c}\text { Obecność podstrefy } \\
\text { (wszystkie powiaty) }\end{array}$} & \multicolumn{2}{c|}{$\begin{array}{c}\text { Obecność podstrefy } \\
\text { (tylko powiaty ziemskie) }\end{array}$} \\
\cline { 3 - 6 } & & tak & nie & tak & nie \\
\hline 2003 & 93,8 & 96,0 & 91,4 & 81,0 & 75,0 \\
\hline 2004 & 93,7 & 96,0 & 91,3 & 80,9 & 73,8 \\
\hline 2005 & 94,8 & 96,9 & 92,5 & 81,9 & 74,6 \\
\hline 2006 & 95,4 & 97,2 & 93,5 & 82,8 & 75,5 \\
\hline 2007 & 96,7 & 98,3 & 95,0 & 84,2 & 76,9 \\
\hline
\end{tabular}

Źródło: opracowanie autora na podstawie danych GUS.

Analizując powiązanie wskaźnika przedsiębiorczości z poziomem bezrobocia rejestrowanego w powiatach obliczono współczynnik korelacji liniowej. Otrzymana wartość 0,30 świadczy o pewnym, aczkolwiek niewielkim, wpływie przedsiębiorczości na poziom bezrobocia. Ujemny charakter zależności ma wydźwięk pozytywny - im wyższy wskaźnik przedsiębiorczości, tym bezrobocie niższe. Nieco lepsze wyniki otrzymano, korelując wskaźnik przedsiębiorczości z wysokością wynagrodzenia w powiecie. Dla badanej grupy powiatów zależność ta wyniosła 0,42 .

\section{Wnioski}

W planach rozwoju opracowanych w momencie tworzenia stref zakładano powstanie w nich co najmniej 100 tys. miejsc pracy. Dziś wiemy, że w 13 lat po utworzeniu pierwszej strefy plan ten został zrealizowany z nawiązką. Specjalne strefy ekonomiczne, jako formuła instytucjonalno-prawna, zakończą swoje funkcjonowanie w 2020 r. Do tego czasu niewątpliwie przyczynią się do dalszego rozwoju działających w SSE przedsiębiorstw oraz do tworzenia nowych miejsc pracy. Jednak z perspektywy długookresowej zarządzający już dziś powinni skoncentrować się na poszukiwaniu przewag komparatywnych stref, umożliwiających działającym w SSE firmom utrzymanie wysokiej pozycji konkurencyjnej również po $2020 \mathrm{r}$. Dobrym sposobem na zatrzymanie firm w obecnych miejscach jest ewolucja stref w klastry przemysłowe, które jeszcze bardziej zwiążą przedsiębiorców ze społecznością lokalną.

Obecnie zapanowało przekonanie, że SSE przestały być skutecznym instrumentem wspierania rozwoju regionalnego. Nowe ustawodawstwo jeszcze bardziej liberalizuje pierwotne założenia. W niedalekiej przyszłości przedsiębiorstwo działające poza strefą będzie mogło, po spełnieniu 
kilku warunków, zostać włączone w jej granice i na równi z innymi korzystać z preferencji podatkowych. Pozwoli to na rozszerzenie stref bez konieczności tworzenia nowych miejsc pracy czy ponoszenia dodatkowych kosztów inwestycyjnych. Z narzędzia polityki regionalnej SSE stały się formą pomocy prywatnym przedsiębiorstwom. W literaturze przedmiotu spotyka się stwierdzenia, że SSE są obecnie substytutem polityki regionalnej (Dziemianowicz, Hausner, Szlachta 2000).

Pomimo początkowych trudności z przyciąganiem inwestorów i komplikacji związanych z wątpliwościami Komisji Europejskiej, SSE w ostatnich latach rozwijają się bardzo dynamicznie. Choć wypaczony został ich pierwotny charakter jako narzędzia wspierania obszarów najsłabszych ekonomicznie, ich wpływ na rozwój lokalny jest zauważalny. Przejawia się on m.in.:

- rozwojem przedsiębiorczości lokalnej;

- szybszą poprawą wskaźników gospodarczych w powiatach, w których zlokalizowano strefy;

- generowaniem przez firmy ze stref dodatkowego zapotrzebowania na rozwój innych dziedzin gospodarki;

- redukcją bezrobocia;

- wzrostem eksportu;

- zwiększeniem konkurencyjności;

- zagospodarowaniem niewykorzystanych terenów;

- rozwojem szkolnictwa wyższego;

- wzrostem siły nabywczej.

Zalety i wady stref nie są jeszcze do końca poznane, instrument ten wciąż znajduje się bowiem w fazie rozwoju. Ich rzeczywisty wpływ na rozwój gospodarczy układów lokalnych i regionalnych będzie można zbadać dopiero za kilkanaście lat, ale dla wielu gmin są one szansą na przezwyciężenie gospodarczego marazmu. Możliwość inwestowania w obrębie stref wydaje się obecnie najbardziej korzystną ofertą, jaką mogą otrzymać podmioty gospodarcze.

Reasumując, należy stwierdzić, że SSE są nadal pożądanym narzędziem przyciągania inwestorów. Pomoc państwa w postaci ulg podatkowych jest co prawda formą krytykowaną przez Unię Europejską, ale z punktu widzenia budżetu państwa najbardziej racjonalną. Udzielanie pomocy rozłożone jest w czasie i nie stanowi wielkiego obciążenia dla budżetu centralnego. Korzyści w postaci wpływów z podatków pośrednich, ceł, podatku dochodowego od osób fizycznych zatrudnionych w strefach czy zmniejszonych wydatków na zasiłki dla bezrobotnych wielokrotnie przewyższają wydatki. Bardzo ważna jest też pewność uzyskania oczekiwanych efektów. W przypadku działalności w strefie przedsiębiorca korzysta ze zwolnień podatkowych dopiero po uruchomieniu produkcji i uzyskaniu dochodu. Gwarancji takich nie dają dotacje bezpośrednie.

\section{Literatura}

1. Bezdeń P., Spallek W., 2008, Specjalne strefy ekonomiczne w przestrzeni gospodarczej województwa dolnoślaskiego [w:] Z. Zioło, T. Rachwał (red.), Procesy transformacji układów przestrzennych przemystu na tle zmieniajacego się otoczenia, „Prace Komisji Geografii Przemystu”, 10/2008, s. 217-229.

2. Dziemianowicz W., Hausner J., Szlachta J., 2000, Restrukturyzacja ośrodków monokulturowych na przyktadzie Mielca, IBnGR, Gdańsk.

3. Dziesięć lat doświadczeń pierwszej polskiej specjalnej strefy ekonomicznej, Mielec 1995-2005, 2005, B. Domański, K. Gwosdz (red.), IGiGP UJ, Kraków. 
4. Gwosdz K., Kwiecińska K., 2005, Wplyw specjalnej strefy ekonomicznej Euro-Park Mielec na rynek pracy [w:] B. Domański, K. Gwosdz (red.), Dziesięć lat doświadczeń pierwszej polskiej specjalnej strefy ekonomicznej. Mielec 1995-2005, IGiGP UJ, Kraków.

5. Korycińska T., 2005, Specjalne strefy ekonomiczne 10 lat później, „Magazyn Strefa”, KSSE, Katowice.

6. Kryńska E., 2000, Polskie specjalne strefy ekonomiczne - zamierzenia i efekty, Scholar, Warszawa.

7. Mazur K., 2004, Specjalne strefy ekonomiczne jako nowe obszary przemystowe, Wydawnictwo Politechniki Śląskiej, Gliwice.

8. Przedsiębiorczość w Polsce 2004, 2004, Ministerstwo Gospodarki i Pracy, Warszawa.

9. Przedsiębiorczość w Polsce 2007, 2007, Ministerstwo Gospodarki, Warszawa.

10. Regiony, miejsca pracy, innowacje. Działania Ministra Gospodarki za 12 miesięcy, Ministerstwo Gospodarki, Warszawa, listopad $2006 \mathrm{r}$.

11. Specjalne Strefy Ekonomiczne. Badanie - edycja 2007 rok, Raport KPMG, Warszawa 2007.

12. Ustawa o specjalnych strefach ekonomicznych z dnia 20 października 1994 r., DzU Nr 123, poz. 600.

13. Ustawa z dnia 16 listopada 2000 r. o zmianie ustawy o specjalnych strefach ekonomicznych oraz o zmianie niektórych ustaw, DzU Nr 117, poz. 1228.

14. Ustawa z dnia 2 października 2003 r. o zmianie ustawy o specjalnych strefach ekonomicznych i niektórych ustaw, DzU Nr 188, poz. 1840.

15. Ustawa z dnia 23 czerwca 2006 r. o zmianie ustawy o specjalnych strefach ekonomicznych i niektórych ustaw, DzU Nr 141, poz. 997.

16. Ustawa z dnia 30 maja 2008 r. o zmianie ustawy o specjalnych strefach ekonomicznych, DzU Nr 118, poz. 746.

\section{Special Economic Zones as a Stimulator of Entrepreneurship}

One of the ways to stimulate the social and economic development is the stimulation of entrepreneurship by the creation of appropriate conditions for the activity of the enterprises. There are good reason why sometimes entrepreneurship is called the fourth factor of production, alongside with the labor, land and capital. Creation the special economic zones (SEZs) in the weakly developed or affected by problem of high unemployment areas is one of the solutions that facilitate doing a business. SEZs were created not only to attract the investments from outside, but also to stimulate the local entrepreneurship.

This study should clarify the influence of SEZs on the entrepreneurship development. According to the presumptions the lands belonging to the special economic zones have better economic indicators than adjacent areas. The analysis can answer the question: What is the influence of tax reliefs and other preferences used in the SEZs on the entrepreneurship development? 